Pak. j. sci. ind. res. Ser. A: phys. sci. 2019 62A(1) 38-47

\title{
Improving Poly(Lactic acid) Properties by Using Fibre Reinforcement of Wild Silkworm Attacus atlas
}

\author{
Yuni Cahya Endrawati ${ }^{a *}$, Dedy Duryadi Solihin ${ }^{b}$, Ani Suryani ${ }^{c}$ and Subyakto ${ }^{d}$ \\ ${ }^{a}$ Department of Animal Production and Technology, Faculty of Animal Science, \\ Bogor Agricultural University, Bogor, Indonesia \\ ${ }^{b}$ Department of Biology, Faculty of Math and Natural Science, Bogor Agricultural University, Bogor, Indonesia \\ ${ }^{c}$ Department of Agricultural Industry Technology, Faculty of Agricultural Technology, \\ Bogor Agricultural University, Bogor, Indonesia \\ ${ }^{\mathrm{d}}$ Research Center for Biomaterials, Indonesian Institute of Sciences, Bogor, Indonesia \\ (received October 23, 2017; revised March 7, 2018; accepted May 16, 2018)
}

\begin{abstract}
Poly lactic acid (PLA) modification is needed to improve PLA properties. This can be done by adding natural fibre to the PLA matrix. This study aims to investigate both the thermal and mechanical properties of Attacus atlas fibre (cocoon and degummed fibre (DF)) and its biocomposites (PLA/Attacus atlas fibre). The thermal behaviour of $A$. atlas cocoon has a significant effect to heat treatment $(\mathrm{P}<0.05)$ at 280 , while DF at 240 based on colour change, weight loss, and fourier transform infrared (FTIR) spectroscopy whicht shows that $A$. atlas fibre can withstand temperatures of 180-200. The mechanical and thermal properties of the biocomposites of PLA/Attacus atlas fibre were investigated using tensile strength, tensile modulus, thermal strength, and FTIR. The $A$. atlas fibre weight both DF and non-degummed fibre (NDF) content of 5, 10 and $15 \mathrm{wt} \%$ was observed in PLA matrix. The addition of 5 degummed fibre $(5 \%$ DF) to PLA increased the pure PLA tensile strength by $8 \%$ and produced the highest tensile modulus ( 2.24 GPa). The data indicated that the addition of PLA $/ 5 \%$ DF will improve the mechanical properties of PLA. The addition of $A$. atlas fibre to the PLA changes the thermal character of the PLA, characterised by crystallinity degree changes.
\end{abstract}

Keywords: Attacus atlas, mechanical properties, thermal properties, tensile strength, tensile modulus

\section{Introduction}

Plastics are widely used and dominate almost all human needs including packaging (38\%), building and construction (21\%), automotive (7\%), electrical equipment (6\%), and other needs (28\%) (European Commission, 2011). However, the dominance of high plastic demand has a serious impact on the environment. Plastic comes from non-renewable materials (petroleum) and causes problems through the accumulation of plastic waste that takes hundreds of years to degrade.

Poly lactic acid (PLA) is one of the alternatives to plastic-based materials that is categorised as an environment friendly polymer made of corn and it degrades naturally into humus, carbon dioxide, and water in a few weeks (Placket and Sodergard, 2005). It could be used for food packaging based on EU Commission Regulation 10/2011, 14 ${ }^{\text {th }}$ January 2011 (Corbion, 2016). At present, PLA is one of the solutions to address the world's synthetic plastic problem. However, PLA needs modification to expand its use as *Author for correspondence: E-mail: y.cahya82@gmail.com a bioplastic. As such, the addition of natural fibres to the PLA may be of use. Natural fibres have excellent mechanical properties that could reinforce the properties of PLA. The addition of $20 \%$ kenaf fibre to PLA composites can increase the PLA's thermal strength from 69 to $120{ }^{\circ} \mathrm{C}$ and its flexural modulus from 4.5 GPa to 7.6 GPa (Placket and Sodergard, 2005).

Attacus atlas fibre is a natural fibre synthesised from the A. atlas silkworm. This insect, also known as the wild silkworm, is found across almost all regions of Indonesia (Kundu et al., 2012; Peigler, 1989). They are thriving due to the country's climate and its food sources. The conservation status of $A$. atlas is recorded as a nonendangered species (UNEP, 2017), so it is safe to use. This insect produces a large size cocoon, weighing $6.37 \pm 1.07 \mathrm{~g}$ (Endrawati and Fuah, 2012) and thus its silk fibre is of great use and benefit.

Attacus atlas fibre consists of two proteins, namely fibroin and sericin. Fibroin is a protein fibre produced by the degumming process of the cocoon, to remove its sericin. Both DF and NDF have an excellent tensile 
strength for composite materials; the tensile strength of NDF is $417-607 \mathrm{MPa}$, while the DF is 879-1689 $\mathrm{MPa}$ (Endrawati et al., 2017). Their tensile strength is generally higher than cotton, jute, flax, ramie, or sisal fibres (Ku et al., 2011) as well as Bombyx mori fibres (with and without sericin), collagen, tendon, and bone (Altman, 2003). The addition of the $A$. atlas fibre to the PLA matrix aims to reinforce the properties of and produce environment friendly composites. The result of this study is a new breakthrough for the use of new material from wild silkworm fibres in biocomposites.

This study aims to investigate the mechanical and thermal properties of $A$. atlas fibre and biocomposites of PLA/Attacus atlas fibre. Fibre analysis is important to ensure that the fibre can withstand exposure to high temperatures (around $180{ }^{\circ} \mathrm{C}$ ) during the biocomposite manufacturing process. The thermal properties of the fibre must be examined to achieve these critical temperatures during biocomposite processing. It is necessary to discover the thermal properties of the fibre so that there will be no degradation in quality at the time of handling and processing. Therefore, this is the initial stage that characterises this study.

\section{Materials and Methods}

Materials. Biocomposites contain two materials that are the fibre and polymer matrix. Fibres were obtained from the $A$. atlas cocoon on a mahogany host plant in Imogiri, Special Region of Yogyakarta, Indonesia. The polymer matrix is PLA Purapol LX175 Corbion Purac.

Heat treatment of fibres. The samples used were the Attacus atlas cocoon (as NDF) and DF with the same range of colours, whitish brown (lightness (L) = 58.482 .00 , red or green $(a)=9.400 .42$, and yellow or blue $(b)=17.450 .45)$. The cocoon is a pupal casing, which is a bunch of silk fibres, while DF refers to the degummed fibre extracted from the cocoon. Degumming starts by putting the cocoon, as much as $0.01 \mathrm{~g} / \mathrm{mL}$, into a solution (distilled water and $0.25 \mathrm{~N} \mathrm{NaOH}$ with a ratio of $2: 1$ ), and then fed into an autoclave Tommy High-Pressure Steam Steriliser ES-315 at $129{ }^{\circ} \mathrm{C}$ for $70.36 \mathrm{~min}$ (Endrawati, 2012). Then the cocoon and DF are put through heat treatments using a Nabertherm furnace $30-3000{ }^{\circ} \mathrm{C}$ at $100-320{ }^{\circ} \mathrm{C}$ for $30 \mathrm{~min}$ at each temperature level. The characterisation for the heat treatment consists of 1 ) colour change $(\Delta \mathrm{E})$ (a Colour Reader CR-10 Konika Minolta Sensing Inc. Japan was used for this (Konika Minolta, 2017), (2) weight loss $(\%)$, and (3) Fourier transform infrared spectroscopy (FTIR) using a Fourier Transform Infrared Bruker Tensor 37.

Colour change is used to detect fibre changes before heat treatment and after heat treatment. In the colour reader, the value just appears as L (lightness), a (red/green), and b (yellow/blue). Therefore, to know the colour lightness difference $(\Delta \mathrm{L})$, difference of $\mathrm{red} / \mathrm{green}(\Delta \mathrm{a})$, and difference of yellow/blue $(\Delta \mathrm{b})$, data must be collected before treatment and symbolised as $\mathrm{L}_{0}, \mathrm{a}_{0}$, and $\mathrm{b}_{0}$ and after treatment and symbolised as $\mathrm{L}_{1}$, $a_{1}$, and $b_{1}$. The colour change formulation can be calculated by equation 1 :

$$
\text { Colour change }(\Delta \mathrm{E})=\sqrt{ }\left[\left(\Delta \mathrm{L}^{2}\right)+\left(\Delta \mathrm{a}^{2}\right)+\left(\Delta \mathrm{b}^{2}\right)\right] \ldots .1
$$

where:

$(\Delta \mathrm{L})=$ the colour lightness difference $\left(\mathrm{L}_{0}-\mathrm{L}_{1}\right) ;(\Delta \mathrm{a})=$ the value of the red or green difference $\left(a_{0}-a_{1}\right)$, and $(\Delta b)$ $=$ the value of the yellow or blue difference $\left(b_{0}-b_{1}\right)$.

The weight loss is the difference in weight before and after the heat treatment. The weight loss formulation can be calculated by equation 2 :

$$
\text { Weight loss }(\%)=\frac{\mathrm{W}_{0}-\mathrm{W}_{\mathrm{t}}}{\mathrm{W}_{0}} \times 100 \ldots \ldots \ldots \ldots \ldots \ldots \ldots \ldots \ldots \ldots \ldots \ldots \ldots \ldots \ldots
$$

where:

$\mathrm{W}_{0}=$ the non-treated fibre weight and $\mathrm{w}_{\mathrm{t}}=$ the fibre weight at a certain temperature treatment.

Preparation of biocomposite processing. The biocomposites consist of two components, a fibre and a polymer. This study used NDF and DF Attacus atlas as a fibre and PLA as a polymer. PLA must be treated first at $100{ }^{\circ} \mathrm{C}$ for four hours before mixing with the fibre (Corbion, 2016). NDF has a length of $4.22 \pm$ $1.65 \mathrm{~mm}$ and a diameter of $20.93 \mu \mathrm{m}$, while DF has a length of $4.22 \pm 1.52 \mathrm{~mm}$ and a diameter of $20.95 \mu \mathrm{m}$ (Fig. 1). NDF is derived from the cocoon that is treated mechanically without solvent chemicals, while DF is derived from degumming by combining mechanical and chemical treatment, like the DF sample in heat treatment. Fibre samples (NDF or DF) have a mixing ratio to PLA of 5, 10 and $15 \%$ (wt fibre to PLA). The biocomposites of NDF to PLA are called PLA/NDF, while the biocomposites of DF to PLA are called PLA/DF 

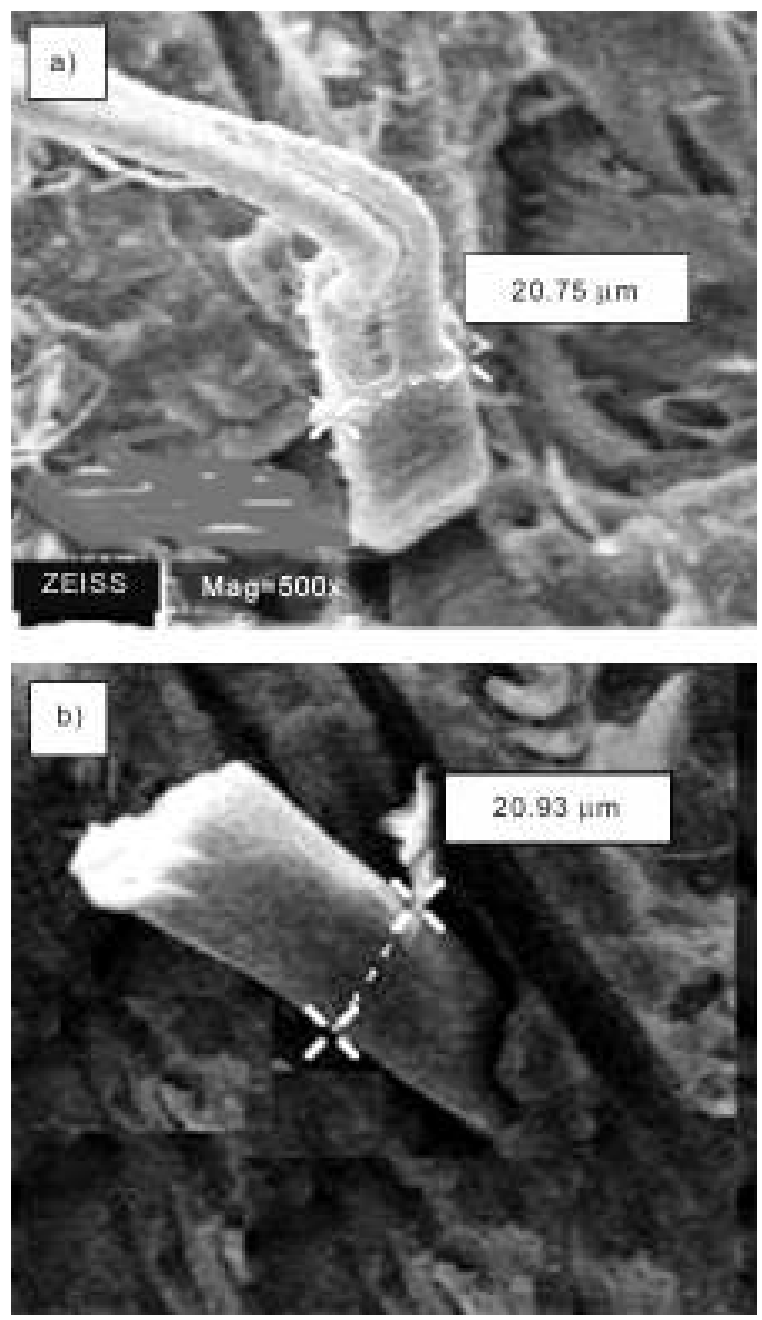

Fig. 1. Diameter of non-degummed fibre (NDF) (a), and degummed fibre (DF) (b) Attacus atlas. (Magnification 500×)

The biocomposite process consists of two stages, mixing and moulding. A Thermo Haake Polydrive was used in the mixing process at $180{ }^{\circ} \mathrm{C}$ in all extruder zones with a mixing speed of $100 \mathrm{rpm}$ for $10 \mathrm{~min}$. The mixing results were split into small pieces to simplify the moulding process. The moulding process consisted of three stages, first, melting for 4-5 min; second, pressing for one minute; and third, cooling for five minutes at $180{ }^{\circ} \mathrm{C}$. Biocomposites were moulded with a density of $1 \mathrm{mg} / \mathrm{mm}^{3}, 1 \mathrm{~mm}$ thick, $60 \mathrm{~mm}$ long, and $50 \mathrm{~mm}$ wide (ASTM, 2016).

The characterisation for the biocomposites consist of mechanical and physical properties, FTIR spectral and Scanning Electron Microscope (SEM).
1. The mechanical characterisation was conducted according to the ASTM D638 standard with the Universal Testing Mechanical Shimadzu AG-IS 50kN (Fig. 2). The tensile strength was tested using a load cell of $1 \mathrm{KN}$ at a tensile speed of $2 \mathrm{~mm} / \mathrm{s}$.

2. To characterise the thermal properties, a Differential Scanning Calorimetry (DSC) 4000 Perkin Elmer was used to measure the melting temperature $(\mathrm{Tm})$, the crystallinity temperature (Tc), melting point enthalpy $(\Delta \mathrm{Hm})$, and the crystallinity degree $(\mathrm{Xc})$ by equation 3 . There were four processes in the DSC. First, the temperature was kept at 25 for $2 \mathrm{~min}$. Then, the heating was carried out at $25-300^{\circ} \mathrm{C}$ with a speed of $10^{\circ} \mathrm{C} / \mathrm{min}$. Next, the temperature was kept at $300{ }^{\circ} \mathrm{C}$ for two minutes. Finally, the cooling was done at $300-25{ }^{\circ} \mathrm{C}$ with a speed of $10^{\circ} \mathrm{C} / \mathrm{min}$. The result is displayed in the thermogram in the form of Tc, Tm, and $\Delta \mathrm{Hm}$.

The degree of crystallinity (Xc) was calculated according to Yong et al. (2010); Sha et al. (2009); Hoi et al. (2008) and can be obtained by:

$$
\mathrm{Xc} \%=\frac{\Delta \mathrm{Hm}}{93.1} \times 100
$$

where:

$\Delta \mathrm{Hm}=$ the melting point enthalpy and $93.1=$ the melting point enthalpy of $100 \%$ crystallinity.

3. For FTIR analysis, a Bruker Tensor 37 was used to determine the effect of heat treatments on the fibre and to detect the interface bonds between the fibres and the PLA matrix in biocomposites. The sample (biocomposite) in form of a pellet was made using a mini hand press. The pellet's composition was $200 \mathrm{mg} \mathrm{KBr}$ and $2 \mathrm{mg}$ biocomposite that was homogenised using a mortar. The pellet was put into the FTIR device in the range of wavenumbers $400-3500 / \mathrm{cm}$. The sample of infrared absorption was displayed in the form of wavenumber spectra at $\mathrm{cm}^{-1}$.

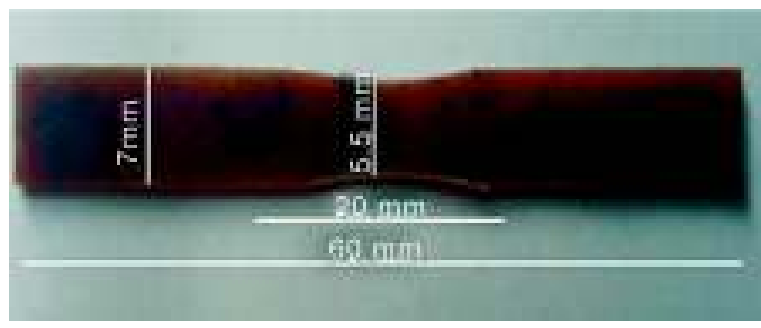

Fig. 2. Sample dimentions of PLA/Attacus atlas fibre biocomposite. 
4. SEM analysis using a Carl Zeiss Bruker EVO MA10 was performed to see the morphology of the biocomposite fracture due to the tensile test so that the bond between fibre and PLA matrix could be clearly seen. SEM analysis began with the coating of a biocomposite sample with gold on a copper template prior to its inclusion in the SEM device. The gold layer served as a conductive coating to enhance the picture image produced by the SEM.

Data analysis. Data on heat treatment (colour change and weight loss) and biocomposites (mechanical and thermal properties) were analysed by ANOVA with completely randomised design.

\section{Results and Discussion}

Thermal properties of Attacus atlas cocoon. The material resistance of heat could be seen from changes in the fibre colour $(\Delta \mathrm{E})$, percentage weight loss, and FTIR spectra wavenumbers. Attacus atlas cocoons have a grey colour $(\mathrm{L}=57.83 \pm 2.82, \mathrm{a}=9.50 \pm 0.97$, and $\mathrm{b}=17.30 \pm 1.61)$ before treatment. It did not change in colour up to $200{ }^{\circ} \mathrm{C}$ of heat treatment but there was a significant change to reddish brown at $240{ }^{\circ} \mathrm{C}(\mathrm{P}<$ 0.05 ) with a colour change of $6.75 \pm 0.44$ (Fig. 3). The cocoon started turning dark brown $(\Delta \mathrm{E}=27.08 \pm 1.73)$ at $280{ }^{\circ} \mathrm{C}$ and started to get black at $320^{\circ} \mathrm{C}$. The rate of browning increased (as a colour change to brown) depending on the temperature and water activities $\left(a_{w}\right)$ (Nursten, 2005). The bound water decreased as the temperature increased and lead-free volume mobility was reduced. The bound water was completely removed at glass temperature (Tg). Bombyx mori fibre has a $\mathrm{Tg}$ of $178{ }^{\circ} \mathrm{C}$ (Hu et al., 2007), while tussah fibroin has $\mathrm{Tg}$ of $190^{\circ} \mathrm{C}$ (Freddi et al., 1997). This aligns with the results in Fig. 3; under $200^{\circ} \mathrm{C}$ there would not be any significant colour change because the browning process went slowly, while above $200{ }^{\circ} \mathrm{C}$ there was a significant colour change and percentage of weight loss (Fig. 3; Table 1).

Colour change was followed by an increase in weight loss (Fig. 3). Weight loss changed significantly above $\mathrm{Tg}$ because some intermolecular bound water evaporated. Heat treatment between 250 up to $350{ }^{\circ} \mathrm{C}$ revealed a chemical transition of fibre and produced new aromatic compounds at $350^{\circ} \mathrm{C}$ (Se et al., 2015). This condition could deliver increasing weight loss. At $320^{\circ} \mathrm{C}$, the cocoon began to darken and it corresponded with the cocoon decomposition temperature. Bombyx mori

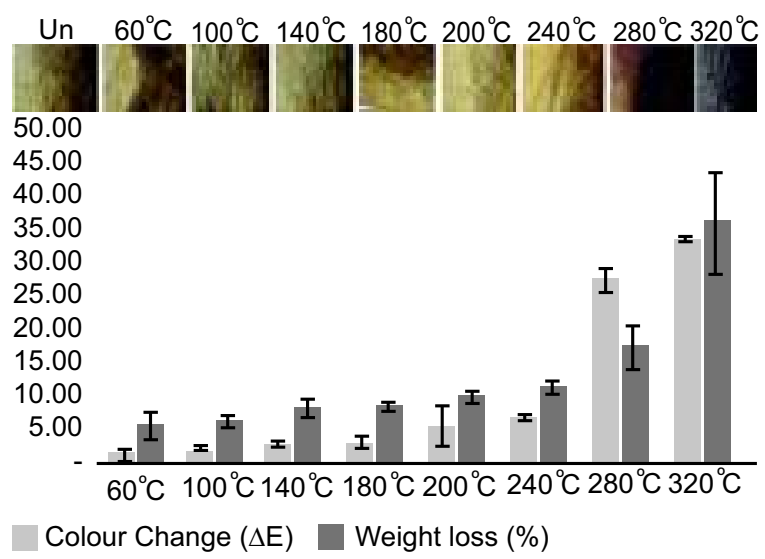

Fig. 3. Colour change and weight loss of Attacus atlas cocoon in heat treatments. $\mathrm{Un}=$ untreatment.

Table 1. Colour change and weight loss percentage of Attacus atlas cocoon

\begin{tabular}{lll}
\hline $\begin{array}{l}\text { Heat treatment } \\
\left({ }^{\circ} \mathrm{C}\right)\end{array}$ & $\begin{array}{l}\text { Colour changes } \\
(\Delta \mathrm{E})\end{array}$ & $\begin{array}{l}\text { Weight loss } \\
(\%)\end{array}$ \\
\hline 60 & $1.06 \pm 0.84^{\mathrm{c}}$ & $5.54 \pm 1.83^{\mathrm{c}}$ \\
100 & $1.94 \pm 0.31^{\mathrm{bc}}$ & $6.19 \pm 0.75^{\mathrm{c}}$ \\
140 & $2.66 \pm 0.47^{\mathrm{bc}}$ & $8.10 \pm 1.27^{\mathrm{c}}$ \\
180 & $2.89 \pm 0.90^{\mathrm{bc}}$ & $8.30 \pm 0.55^{\mathrm{c}}$ \\
200 & $5.42 \pm 2.99^{\mathrm{b}}$ & $9.71 \pm 0.74^{\mathrm{bc}}$ \\
240 & $6.75 \pm 0.44^{\mathrm{b}}$ & $11.16 \pm 0.91^{\mathrm{bc}}$ \\
280 & $27.08 \pm 1.73^{\mathrm{a}}$ & $17.04 \pm 3.27^{\mathrm{b}}$ \\
320 & $33.17 \pm 0.19^{\mathrm{a}}$ & $35.66 \pm 7.41^{\mathrm{a}}$ \\
\hline \hline
\end{tabular}

Means in the same column with different superscripts (a, b, c) differ significantly $(\mathrm{P}<0.05)$.

reaches a decomposition temperature at $312^{\circ} \mathrm{C}$ (Zhang et al., 2002) and tussah silk fibroin at $353^{\circ} \mathrm{C}$ (Freddi et al., 1997). At this stage, amorphous regions were degraded greater than the beta sheet regions and produced significant weight loss.

The cocoon spectra could reinforce the result of the colour change and weight loss. The cocoon has a wavenumber of $3290.93 \mathrm{~cm}^{-1} \mathrm{~N}-\mathrm{H}$ stretching, $1645.11 \mathrm{~cm}^{-1}$ $\mathrm{C}=\mathrm{O}$ stretching $\alpha$-helix, $1517.24 \mathrm{~cm}^{-1} \mathrm{C}-\mathrm{N}$ stretching, $1235.26 \mathrm{~cm}^{-1} \mathrm{~N}-\mathrm{H}$ deformation vibration, $963.70 \mathrm{~cm}^{-1}$ and $696.61 \mathrm{~cm}^{-1}$ as beta sheet, and $621.32 \mathrm{~cm}^{-1} \alpha$-helix (Fig. 4a). Wavenumbers at $3250-3300 \mathrm{~cm}^{-1}$ are $\mathrm{N}-\mathrm{H}$ stretching (Amide II), $1638-1646 \mathrm{~cm}^{-1}$ are $\alpha$-helix $\mathrm{C}=\mathrm{O}$ stretching (Amide I), 1450-1600 $\mathrm{cm}^{-1}$ are beta sheet (Amide II), $700 \mathrm{~cm}^{-1}$ are beta sheet, and 621-664 $\mathrm{cm}^{-1}$ 
are $\alpha$-helix (Gallagher, 2017; Hu et al., 2006; Stuart, 2004; Freddi et al., 1997). While the wave-numbers at $1620 \mathrm{~cm}^{-1}\left(\mathrm{C}=\mathrm{O}\right.$ stretching Amide I), $1520 \mathrm{~cm}^{-1}$ (C-N stretching Amide II), $1230 \mathrm{~cm}^{-1}$ (N-H deformation vibration Amide III), and $3040 \mathrm{~cm}^{-1} \mathrm{~N}-\mathrm{H}$ stretching are the polypeptide bond spectra (Se et al., 2015). Heat treatment could change in the secondary structure of proteins (Fig. 4). Spectra $1641-1644 \mathrm{~cm}^{-1}$ $\mathrm{C}=\mathrm{O}$ stretching (random coil) appears at up to $240^{\circ} \mathrm{C}$ and excess $280^{\circ} \mathrm{C}$ has spectra of $1630-1631 \mathrm{~cm}^{-1}$ (strong
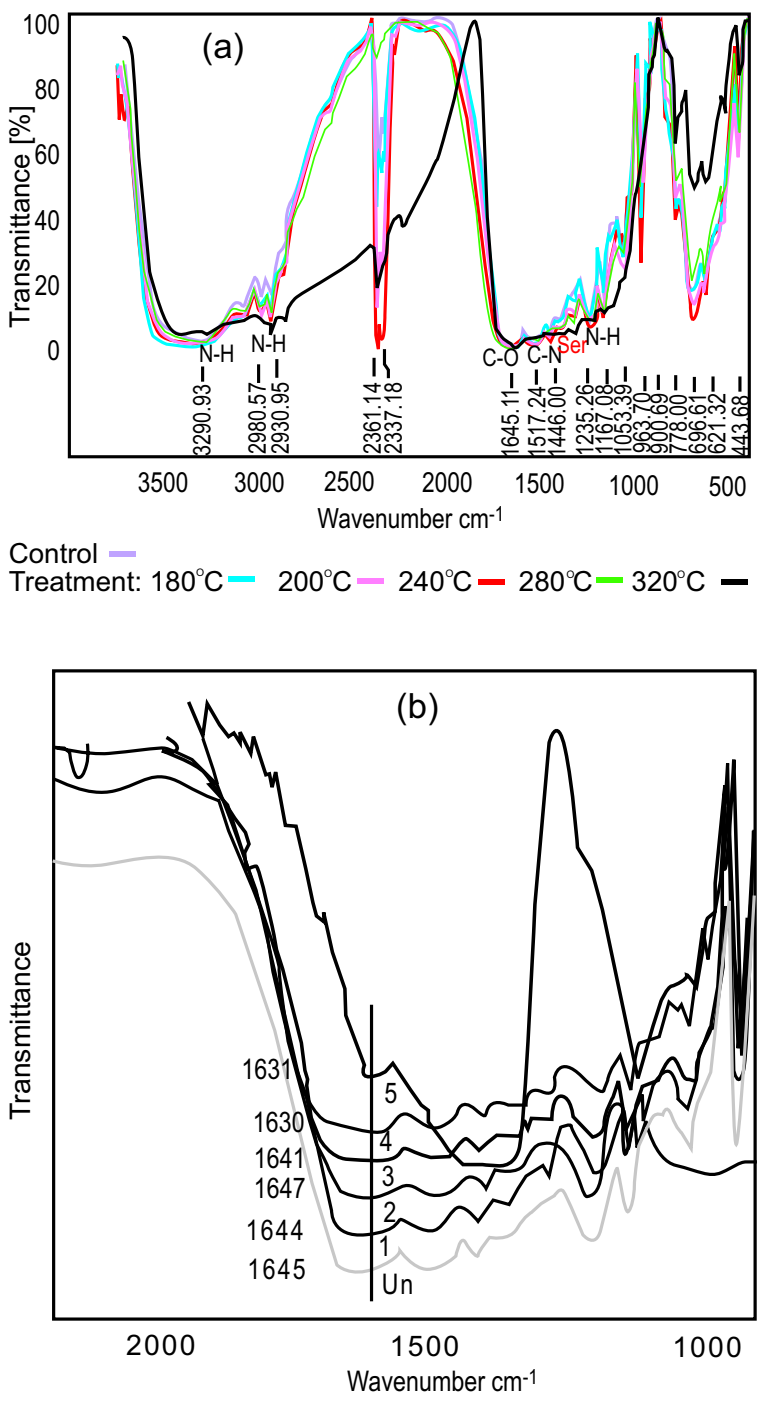

Fig. 4(a-b). Fourier transform infrared (FTIR) spectra of Attacus atlas cocoon, $500-3500 \mathrm{~cm}^{-1}$ (a), $1000-2000 \mathrm{~cm}^{-1}$ (b), untreatment (Un), $180{ }^{\circ} \mathrm{C}(1)$, $200{ }^{\circ} \mathrm{C}(2), 240{ }^{\circ} \mathrm{C}(3), 280{ }^{\circ} \mathrm{C}(4)$, and $320^{\circ} \mathrm{C}(5)$. intramolecular beta sheet) (Fig. 4b). The changes in the wavenumbers indicate a random coil transition to betasheet conformation. These results are consistent with Se et al. (2015) and exhibit clear characteristic peaks of beta-sheet conformation at heat treatment in excess of $280^{\circ} \mathrm{C}$.

The cocoon has heat resistant behaviour, first, water evaporated at around $100{ }^{\circ} \mathrm{C}$ but the colour and weight loss did not change significantly; second, the suspected Tg was at around $200{ }^{\circ} \mathrm{C}$; third, colour and weight loss changes (but not significant) began at around $240{ }^{\circ} \mathrm{C}$ because there are no changes in the chemical structure (by FTIR spectra); and fourth, significant colour and weight loss changes, as well as a transition of random coil structure into beta-sheet, occurred at around 280$320^{\circ} \mathrm{C}$.

Thermal properties of DF. Degummed fibre (DF) is greyish brown $(\mathrm{L}=55.30 \pm 0.42, \mathrm{a}=10.20 \pm 0.71$, and $\mathrm{b}=16.85 \pm 0.35)$. DF colour did not undergo a significant change in the heat treatment up to $200{ }^{\circ} \mathrm{C}(\Delta \mathrm{E}=1.02$ \pm 0.48 ) but it significantly changed at $280^{\circ} \mathrm{C}$. With this heat treatment, DF changed to a dark brown with $\Delta \mathrm{E}$ $=28.81 \pm 3.03$ and weight loss changes of $21.40 \pm$ $4.04 \%$ (Fig. 5). The significant colour changes in the DF corresponded with the percentage of weight loss. At the same level of heat treatment, DF has a colour change and weight loss greater than the cocoon. This might indicate that the chemical structure of DF changes faster than the cocoon. The cocoon has a sericin protein, which has a hydrophilic structure that will protect the

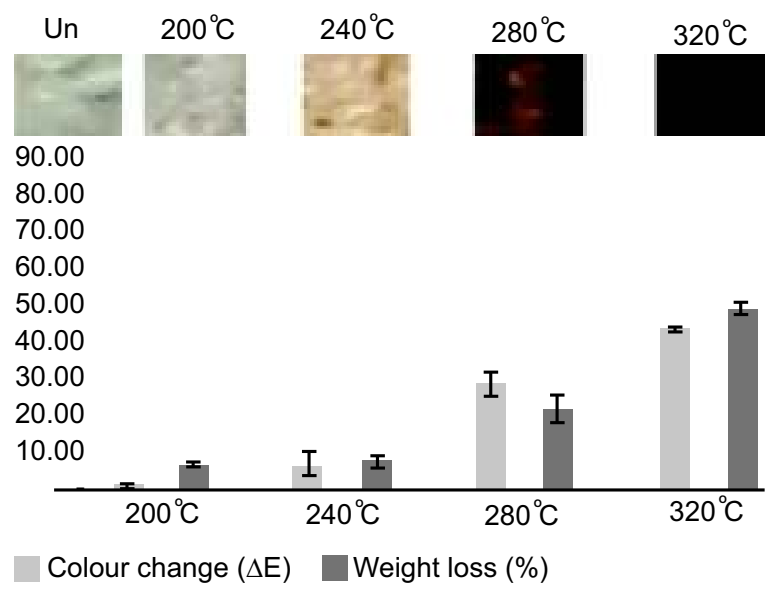

Fig. 5. Colour change and weight loss of Attacus atlas degummed fibre (DF) in heat treatments. Un $=$ untreatment. 
fibroin from heat stress exposure, while DF does not have sericin because it was released during the degumming process. This is supported by the DF spectra; there was no serine amino acid absorption wavenumber and no sericin protein was indicated in the DF (Fig. 6a). Serine is the largest component of amino acids in sericin protein 28-29 (Mondal et al., 2007) and has spectra wavenumbers at $1350-1250 \mathrm{~cm}^{-1}$ (Stuart, 2004).

Figure 6 shows the DF wavenumber before and after heat treatment. There are wavenumbers of 1644.46 $\mathrm{cm}^{-1} \mathrm{C}=\mathrm{O}$ stretching random coil (silk I) at spectra

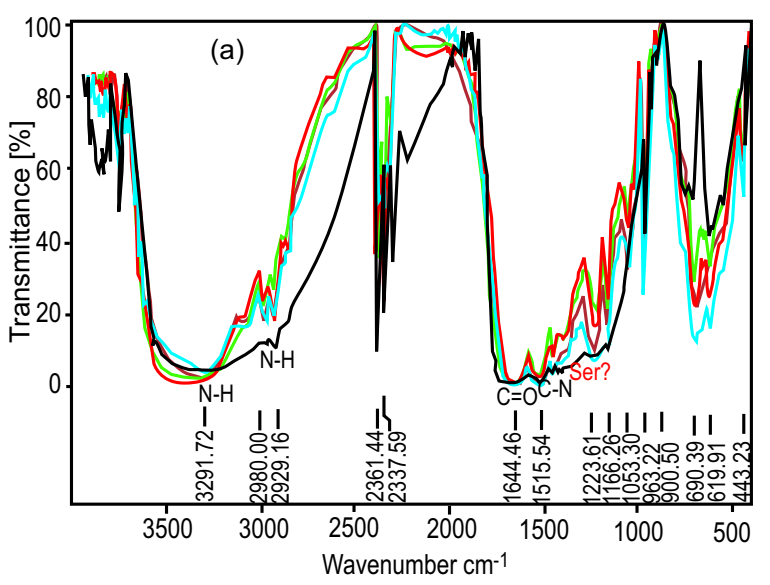

Control -

Treatment: $200^{\circ} \mathrm{C}-240^{\circ} \mathrm{C}-280^{\circ} \mathrm{C}-320^{\circ} \mathrm{C}-$

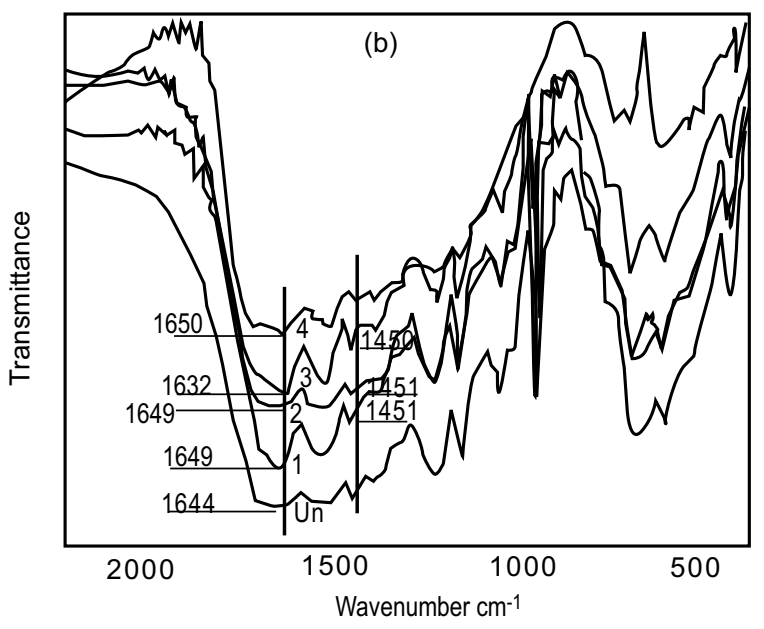

Fig. 6(a-b). Fourier transform infrared (FTIR) spectra of degummed fibre Attacus atlas (DF), 500-3500 $\mathrm{cm}^{-1}$ (a), 500$2000 \mathrm{~cm}^{-1}$ (b), Untreatment (Un), 200 ${ }^{\circ} \mathrm{C}(1), 240{ }^{\circ} \mathrm{C}(2), 280{ }^{\circ} \mathrm{C}(3)$, and $320^{\circ} \mathrm{C}(4)$. before heat treating the fibre and it has new absorption at $1451 \mathrm{~cm}^{-1}$, which is an Amide II crystalline structure after heat treatment of $200-280{ }^{\circ} \mathrm{C}$ (Fig. 6b). The results indicate that a change of the beta sheet becomes stronger and increases the degree of crystallinity, the increase of which corresponds with the increase in heat treatment (Hu et al., 2007). The wavenumber of $1450 \mathrm{~cm}^{-1}$ disappeared at the treatment of $320^{\circ} \mathrm{C}$. This is in line with the report by Se et al. (2015) where the beta sheet began to break down and transformed into sp2hybridised hexagonal carbon at a temperature around $350{ }^{\circ} \mathrm{C}$. This indicates that DF still has good thermal properties up to $280^{\circ} \mathrm{C}$.

Mechanical strength of biocomposite PLA/Attacus atlas fibre. The tensile strength of pure PLA was 56.24 $\pm 2.27 \mathrm{MPa}$, PLA $/ 5 \%$ NDF was $59.62 \pm 4.74 \mathrm{MPa}$, and $\mathrm{PLA} / 5 \%$ DF was $60.74 \pm 4.96 \mathrm{MPa}$. The addition of $5 \%$ DF to the PLA matrix increased the tensile strength by $8 \%$ compared with pure PLA, however, it decreased as the percentage of fibre increased (Table 2). The result was consistent with the prior study by Hoi et al. (2008); $5 \%$ tussah fibre in the PLA matrix produced the highest tensile strength that tends to decrease as the percentage of fibre increases. This condition indicates that the maximum fibre addition to PLA is $5 \%$, more than that will cause a rise in viscosity decreasing the fibre distribution in the matrix.

In general, biocomposites of PLA/DF produced a greater tensile strength compared to PLA/NDF and pure PLA composite (Fig. 7). The biocomposite PLA/DF has a slightly higher ratio stress-stroke curve than others because DF makes up a crystalline region about $75 \%$ greater than an amorphous region of about $25 \%$. The

Table 2. Tensile strength of PLA/Attacus atlas fibre biocomposite

\begin{tabular}{lll}
\hline \hline Treatment & $\begin{array}{l}\text { Tensile strength } \\
\mathrm{MPa}\end{array}$ & $\begin{array}{l}\text { Tensile modulus } \\
\mathrm{GPa}\end{array}$ \\
\hline Pure PLA & $56.24 \pm 2.27^{\mathrm{ab}}$ & $2.23 \pm 0.04^{\mathrm{ab}}$ \\
PLA/5\%NDF & $59.62 \pm 4.74^{\mathrm{a}}$ & $2.14 \pm 0.06^{\mathrm{b}}$ \\
PLA/10\%NDF & $44.78 \pm 2.97^{\mathrm{bc}}$ & $2.33 \pm 0.18^{\mathrm{ab}}$ \\
PLA/15\%NDF & $43.78 \pm 2.97^{\mathrm{bc}}$ & $2.38 \pm 0.24^{\mathrm{ab}}$ \\
PLA/5\%DF & $60.74 \pm 4.96^{\mathrm{a}}$ & $2.24 \pm 0.12^{\mathrm{ab}}$ \\
PLA/10\%DF & $55.77 \pm 6.64^{\mathrm{ab}}$ & $2.34 \pm 0.17^{\mathrm{ab}}$ \\
PLA/15\%DF & $26.28 \pm 4.82^{\mathrm{c}}$ & $2.40 \pm 0.07^{\mathrm{ab}}$ \\
\hline \hline
\end{tabular}

$\mathrm{NDF}=$ non-degummed fibre; $\mathrm{DF}=$ degummed fibre.

Means in the same column with different superscripts ( $a, b$, c) differ significantly $(\mathrm{P}<0.05)$. 
crystalline region contains repetitive amino acids (-GlyAla-Gly-Ala-Gly-Ser-), forming a beta sheet will be the most significant influence on the mechanical properties of the fibre. NDF still contains materials other than fibroin, such as sericin. The presence of sericin in the fibre produces a lower tensile strength than pure fibroin. The sericin contains an amorphous region greater than the crystalline region. The presence of sericin in fibroin decreases the single fibre strength from 610-690 MPa to $500 \mathrm{MPa}$ (Yang and Bochu, 2009).

Interface bonding strength between DF and PLA is in line with the tensile strength of the biocomposite PLA/DF, which is greater than PLA/NDF. The strong interface bonding between the fibre and matrix caused an effective transfer of stress and load distribution through the interface and was ordered to improve the mechanical properties (Franco and Gonzales, 2005). These conditions can be seen in Fig. 8. The biocomposite of PLA $/ 5 \%$ DF seems to have improved the interfacial bonding with the fibre having a shorter length compared to PLA/NDF interfacial bonding with extensive fibre pull-out. The strong interfacial bonding between matrix and fibres is characterised by the breaking of some microfibrils with a shear fracture of the composite (Ray and Rout, 2005). It is indicated that biocomposite PLA $/ 5 \%$ DF has good interfacial bonding between the fibre and matrix.

The interfacial bonding in biocomposite PLA $/ 5 \% \mathrm{DF}$ was affected by the tensile modulus also (Table 2). That biocomposite has the highest tensile modulus $(2.24 \pm 0.12 \mathrm{GPa})$ that indicates a compact and strong composite.

Thermal properties of biocomposite PLA/Attacus atlas fibre. In this study, the melting temperature (Tm) of pure PLA is slightly higher $\left(176.23^{\circ} \mathrm{C}\right)$ than the data from the PLA Corbion $\left(175^{\circ} \mathrm{C}\right)$ by DSC analysis. Increasing the percentage of silk fibres in the PLA matrix did not significantly affect the changes to the $\mathrm{Tm}$ and Tc (Fig. 9). The Tg was not detectable in the termogram because the crystalline structure was already formed on the biocomposite; this is supported by the increase in Tc. This is likely because the heating temperature $\left(300{ }^{\circ} \mathrm{C}\right)$ is too high and damages the matrix, which then magnifies the damage by increasing the fibre percentage. This condition also causes the crystallinity degree to decrease in almost all treatments as fibre percentages increase.

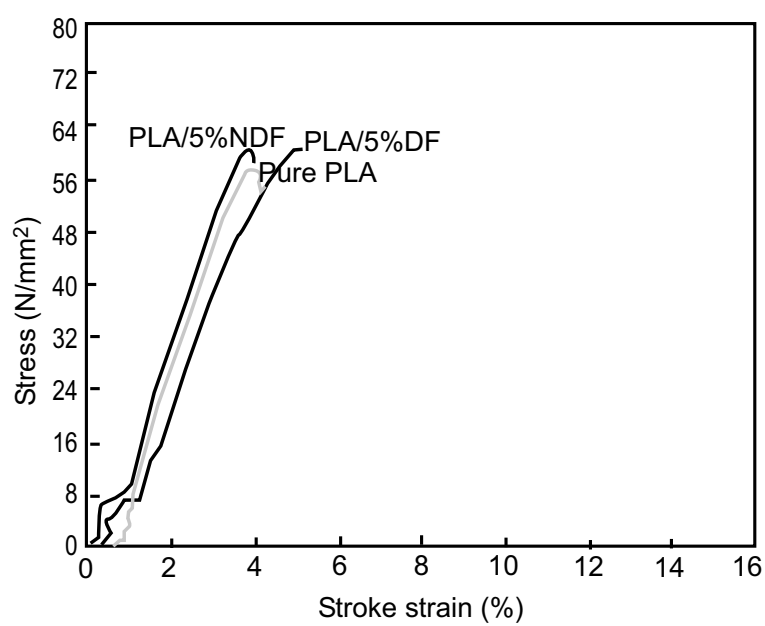

Fig. 7. Stress-strain curve of biocomposit PLA/ Attacus atlas fibre.
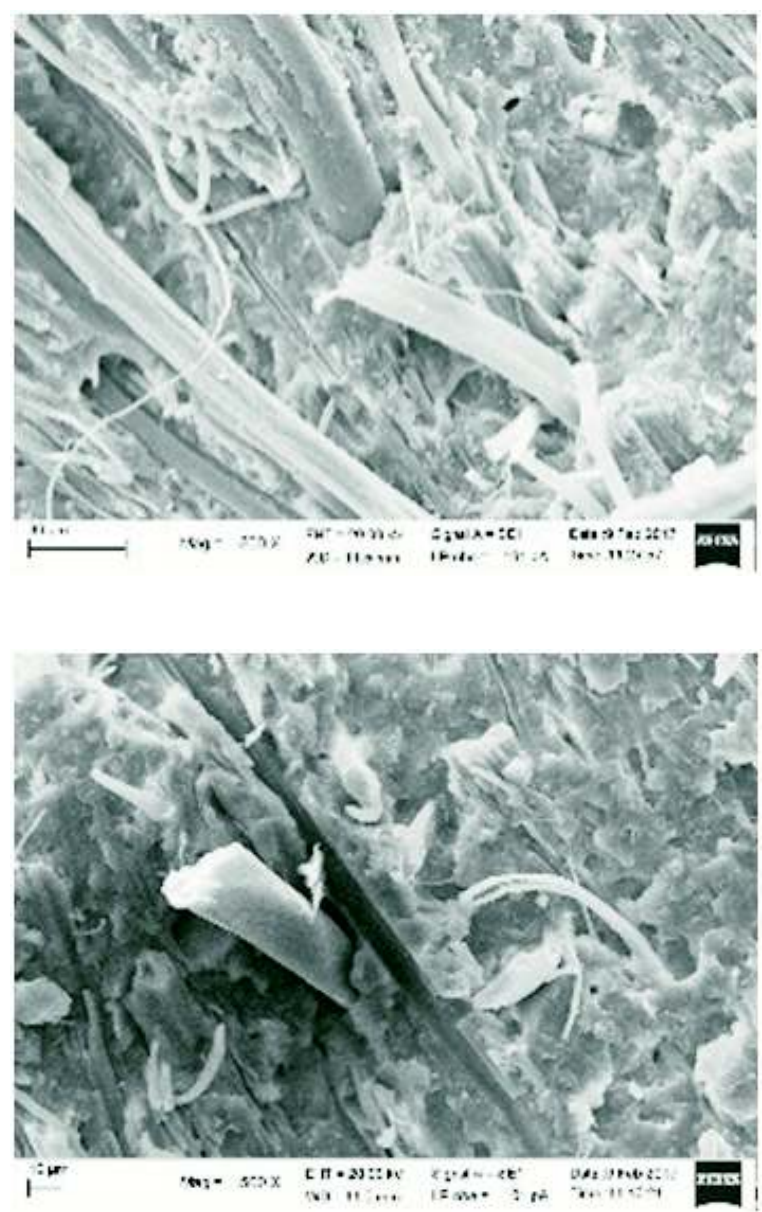

Fig. 8. Fibre fracture by scanning electron microscopy. Magnification 500X. 

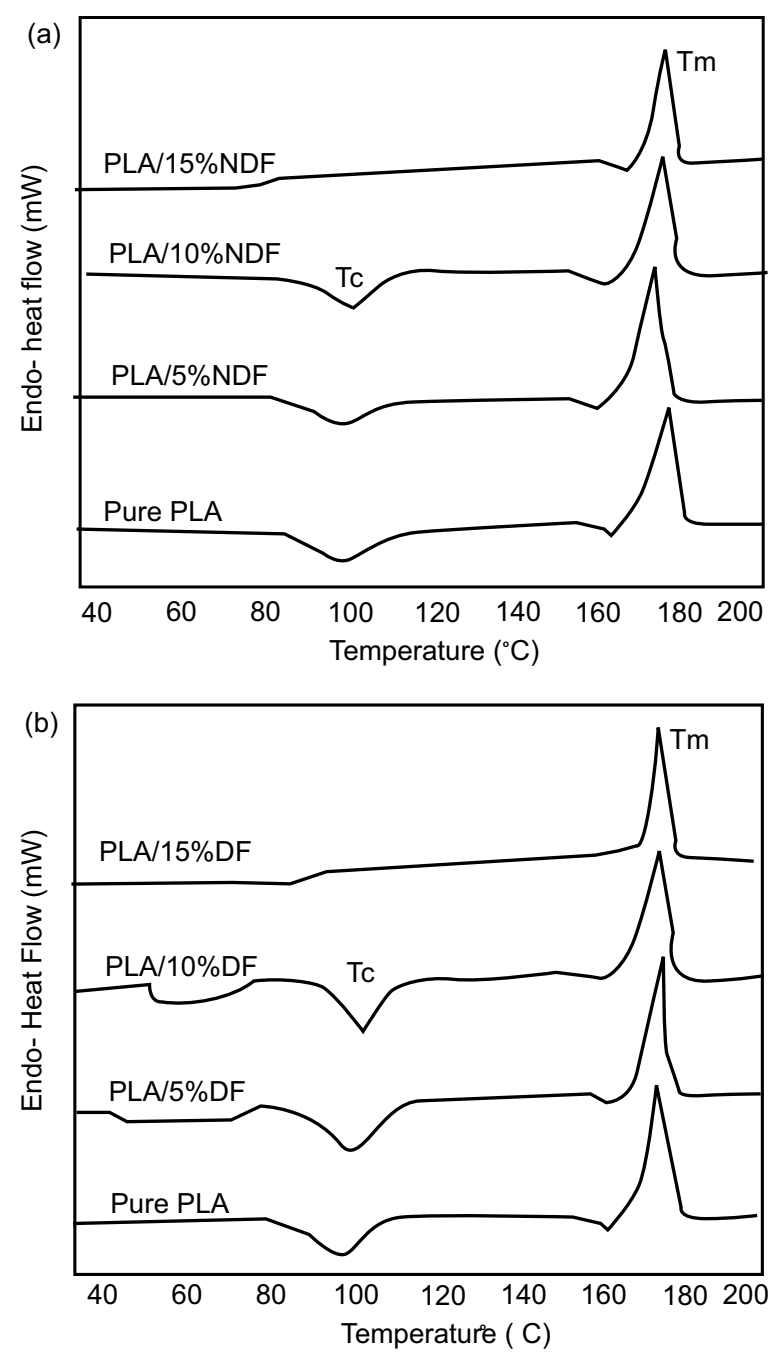

Fig. 9(a-b). Differencial scanning calorimetry (DSC) termogram of biocomposite non-degummed fibre Attacus atlas (PLA/DF) (a), and degummed fibre Attacus atlas (PLA/DF) (b).

The degree of crystallinity decreased as can be seen by the $\Delta \mathrm{Hm}$ values, which tends to decrease as the percentage of fibres increase (Table 3 ). The $\Delta \mathrm{Hm}$ value is the energy enthalpy used to melt per unit area of the biocomposite, so that if energy decreases, it may indicate that the crystallinity degree decreased. A decrease in the crystallinity degree may also indicate a decrease in mechanical strength.

FTIR spectrum of biocomposite PLA/Attacus atlas fibre. FTIR analysis can be used to determine the presence of new materials in biocomposites by looking at changes in the functional group. The pure PLA shows infrared absorption at wavenumbers $3503.01 \mathrm{~cm}^{-1} \mathrm{CH}_{3}$
Table 3. Physical properties of biocomposite Attacus atlas fibre to PLA matrix

\begin{tabular}{|c|c|c|c|c|c|c|}
\hline \multirow[t]{2}{*}{ Treatment } & $\mathrm{Tg}$ & $\mathrm{Tm}$ & $\mathrm{Tc}$ & $\Delta \mathrm{Hc}$ & $\Delta \mathrm{Hm}$ & \multirow{2}{*}{$\begin{array}{l}X c \\
(\%)\end{array}$} \\
\hline & \multicolumn{3}{|c|}{$\left({ }^{\circ} \mathrm{C}\right)$} & \multicolumn{2}{|c|}{$(\mathrm{J} / \mathrm{g})$} & \\
\hline Pure PLA & ND & 176.23 & 97.81 & 21.87 & 45.07 & 48.41 \\
\hline PLA/5\%DF & ND & 175.54 & 100.84 & 29.47 & 43.90 & 47.14 \\
\hline PLA/10\%DF & ND & 174.86 & 102.18 & 25.76 & 38.08 & 40.86 \\
\hline PLA/15\%DF & ND & 176.22 & ND & ND & 26.77 & 28.75 \\
\hline PLA/5\%NDF & ND & 174.56 & 98.98 & 16.29 & 43.03 & 46.22 \\
\hline PLA $/ 10 \% \mathrm{NDF}$ & ND & 175.08 & 99.48 & 19.94 & 40.11 & 43.08 \\
\hline PLA/15\%NDF & ND & 177.03 & ND & ND & 46.05 & 48.39 \\
\hline
\end{tabular}

Note: $\mathrm{Tg}$ and $\mathrm{Tm}$ collected from heating process; while Tc collected from cooling process; $\mathrm{ND}=$ not detectable.

stretching and $1746.97 \mathrm{~cm}^{-1} \mathrm{C}=\mathrm{O}$ stretching (Fig. 10). PLA has an infrared absorption spectrum at wavenumbers $100-3600 \mathrm{~cm}^{-1}, 3000-3500 \mathrm{~cm}^{-1} \mathrm{CH}_{3}$ stretching, $1500-2000 \mathrm{~cm}^{-1} \mathrm{C}=\mathrm{O}$ stretching, and $1000-1500 \mathrm{~cm}^{-1}$ CC (O) -O stretching (Orozco et al., 2009). The addition of $5 \%$ DF and NDF to the PLA matrix did not change the FTIR spectra, but in percentages of $10-15 \%$ DF and NDF, there was new infrared absorption at wavenumbers $1650 \mathrm{~cm}^{-1}$ and $1513 \mathrm{~cm}^{-1}$ (Fig. 10-11).

The wavenumber indicates that bonding between the fibre and matrix has happened. The infrared radiation from FTIR will be absorbed by molecules and cause the vibration of molecules. These vibrations are captured and displayed as absorption of wavenumbers by FTIR. If new wavenumbers appear in the biocomposite spectral and it is identical to the DF or NDF wavenumbers, it shows that a bond between DF or NDF with the matrix PLA has occurred.

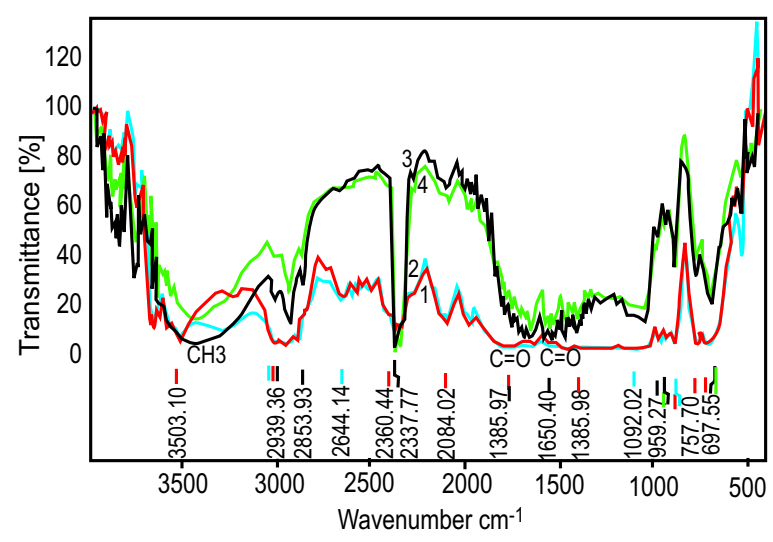

1. Pure PLA 2. PLA/5\%DF 3. PLA/10\%DF 4. PLA/15\%DF

Fig. 10. FTIR spectra of biocomposite PLA/DF. 


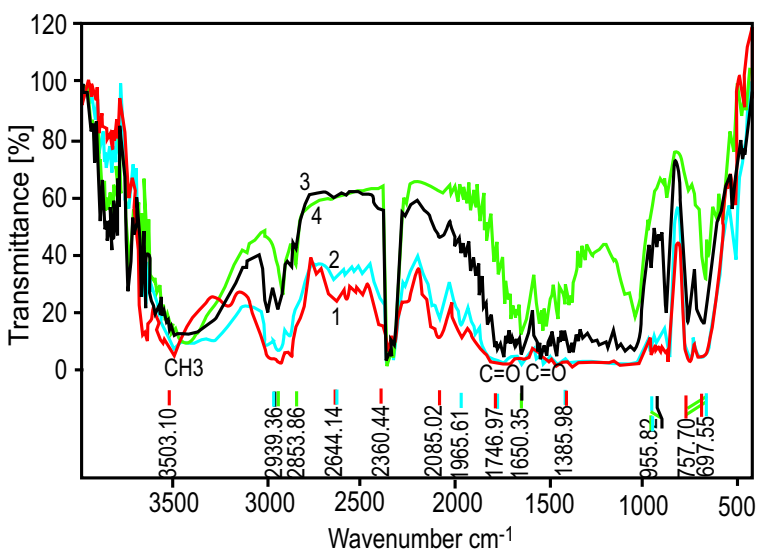

1. Pure PLA 2. PLA/5\%NDF 3. PLA/10\%NDF 4. PLA/15\%NDF

Fig. 11. FTIR spectra of biocomposite PLA/NDF.

\section{Conclusion}

This study found the critical temperature for the use of cocoon and degummed fibre (DF) of Attacus atlas silkworm in Poly lactic acid (PLA). The Attacus atlas cocoon undergoes significant chemical changes at $280^{\circ} \mathrm{C}$ heat treatments, while DF has significant chemical changes at $240^{\circ} \mathrm{C}$, which was analysed by weight loss, colour changes, and FTIR spectra. The thermal properties of Attacus atlas fibres will work well to create a composite at temperatures of $180-200{ }^{\circ} \mathrm{C}$. During the study, difference percentages of $A$. atlas fibre were added to the PLA matrix: $5 \%, 10 \%$, and $15 \%$ wt. The addition of $5 \%$ DF in the PLA matrix can increase the tensile strength by $8 \%$ to improve PLA's mechanical properties. The properties of PLA $/ 5 \%$ DF are comparable to those of other natural fibres used in industrial polymeric composites.

In this study, it was found that sericin has an excellent role in fibre protection and this is evident from the higher cocoon heat resistance than that of DF. However, when it is combined with the PLA matrix, sericin will interfere with the bond between the fibre and the PLA matrix. This has an impact on the mechanical properties of smaller PLA/NDF than PLA/DF biocomposites.

\section{Acknowledgement}

The authors would like to extend their gratitude to Corbion Netherland for supporting this research by providing PLA polymer of semicrystalline L175. Our appreciation also goes to the Scholarship for
Graduate Education of Home Affairs (BPPDN) of Higher Education in Indonesia for financing this research.

Conflict of Interest. The authors declare no conflict of interest.

\section{References}

Altman, G.H., Diaz, F., Jakuba, C., Calabro, T., Horan, R.L., Chen, J., Lu, H., Richmond, J., Kaplan, D.L. 2003. Silk based biomaterials. Biomaterials, 24: 401-416.

ASTM, 2016. ASTM D638-03 Standard Test Method for Tensile Properties of Plastics. American Society for Testing Materials, PA, USA.

Corbion, 2016. Product data purapol L175. Retrieved May 20, 2016 from http://www.corbion.com; media/442284/pds.purapol-1175.pdf

Endrawati, Y.C., Solihin, D.D., Suryani, A., Subyakto, S. 2017. Optimization of silkworm fibroin yield Bombyx mori L. and Attacus atlas L. using response surface methodology. Agritech, 37: 205-214.

Endrawati, Y.C., Fuah, A.M. 2012. Cocoon morphometry Attacus atlas has grown in the laboratory. Indonesian Journal of Animal Science, 14: 337-342.

Endrawati, Y.C. 2012. Sericin Protein Extraction from Attacus atlas Cocoon and Its Characterization as a Biomaterial. Master Thesis, 76 pp., Bogor Agricultural University, Indonesia.

EC, 2011. Plastic waste in the environment. European Commission DG ENV. Revised Final Report, Paris, France.

Franco, P.J.H., Gonzalez, A.V. 2005. Fiber-matrix adhesion in natural fibre composite. In: Natural Fiber, Biopolymers, and Bio composites, pp. 177230, Taylor and Francis Group, Florida, USA.

Freddi, G., Monti, P., Nagura, M., Gotoh, Y., Tsukada, M. 1997. Structure and molecular conformation of tussah silk fibroin films: effect of heat treatment. Journal of Polymer Science Part B, 35: 841-847.

Gallagher, W. 2017. FTIR analysis of protein structure. Retrieved April 21, 2017 from http://www.chem. uwec.edu

Hoi, Y.C., Kin, T.L., Xiao, M.T., Hui, D. 2008. A potential material for tissue engineering: Silkworm silk/PLA bio composite. Composites, 39: 10261033.

Hu, X., Kaplan, D., Cebe, P. 2007. Effect of water on 
the thermal properties of silk fibroin. Thermochimica Acta, 461: 137-144.

Hu, X., Kaplan, D., Cebe, P. 2006. Determining beta sheet crystallinity in fibrous proteins by thermal analysis and infrared spectroscopy. Macromolecules, 39: 6161-6170.

Konika Minolta. 2017. Precise color communication color control from perception to instrumentation. Retrieved August 30, 2017 from htpp://www. konicaminolta.com

Ku, H., Wang, H., Pattarachaiyakoop, N., Trada, M. 2011. A review on the tensile properties of natural fiber reinforced polymer composites. Composite Part B, Engineering, 42: 856-873.

Kundu, S.C., Kundu, B., Talukdar, S., Bano, S., Nayak, S., Kundu, J., Mandal, B.B., Bhardwaj, N., Botlagunta, M., Dash, B.C., Acharya, C., Ghosh, A.K. 2012. Nonmulberry silk biopolymers. Biopolymers, 97: 455-467.

Mondal, M., Trivedy, K., Kumar, S.N. 2007. The silk proteins, sericin and fibroin in silkworm, Bombyx mori Linn. Caspian Journal of Environmental Science, 5: 63-76.

Nursten, H. 2005. The Maillar Reaction Chemistry, Biochemistry and Implications, $214 \mathrm{pp}$. The Royal Society of Chemistry, London, UK.

Orozco, V.H., Brostow, W., Chonkaew, W., Lopez, B.L. 2009. Preparation and characterization of poly (Lactic acid)-g-maleic anhydride starch blends. Macromolecule Symposium, 277: 69-80.

Peigler, R. 1989. A Revision of The Indo-Australian Genus Attacus, 167 pp. The Lepidoptera Research Foundation, Inc. Beverly Hill, California, USA.

Placket, D., Sodergard, A. 2005. Poly lactic-Based Bio composites. In: Natural Fiber, Biopolymers, and
Biocomposites, pp. 579-596, Taylor and Francis Group, Florida, USA.

Ray, D., Rout, J. 2005. Thermoset Bio composites. In: Natural Fiber, Biopolymers, and Bio composites, pp. 291-346, Taylor and Francis Group, Florida, USA.

Se, Y.C., Young, S.Y., Sungho, L., Dawon, J., Kyu, Y.P., Jae, K.K., Byung, H.K., Kisuk, K., Kaplan, D.L., Hyoung, J.J. 2015. Carbonization of a stable bsheet-rich silk protein into a pseudo graphitic pyro protein. Nature Communications, 6: 7145.

Sha, C., Kin, T.L., Tao, L., Yongqing, Z., Pou, M.L., Yansheng, Y. 2009. Mechanical and thermal properties of chicken feather fiber/PLA green composites. Composites, 40: 650-654.

Stuart, B.H. 2004. Infrared Spectroscopy: Fundamentals and Applications, 203 pp., Wiley, NJ, USA.

UNEP, 2017. CITES of Wild Fauna and Flora Appendices I, II and III. Convention on International Trade in Endangered Species (UNEP). Retrieved March 1, 2017 from http://www.cites.ore/eng/app/ appendices.php

Yang, C., Bochu, W. 2009. Biodegradation of silk biomaterials. International Journal of Molecular Sciences, 10: 1514-1524.

Yong, Q.Z., Hoi, Y.C., Kin, T.L., Cai, L.X., Dan, D.Z, Hu, L.L. 2010. Silkworm silk/poly(Lactic acid) biocomposites: Dynamic mechanical, thermal and biodegradable properties. Polymer Degradation and Stability, 95: 1978-1987.

Zhang, H., Magoshi, J., Magoshi, Y., Yoshida, H., Chen, J.Y., Saiki, K. 2002. Inorganic compositions and thermal properties of cocoon fiber. International Journal of Society Material Engineering Resource, 10: 113-116. 